\title{
ORISINALITAS HADIS NABI SAW. PERSPEKTIF ISLAMOLOG
}

\author{
TASMIN TANGNGARENG \\ Fakultas Ushuluddin Filsafat dan Politik \\ UIN Alauddin Makassar \\ Email: tasmin.tangngareng64gmail.com
}

\begin{abstract}
Abstrak:
Artikel ini membahas tentang kajian hadis di kalangan Islamolog. Pemikiran Islamolog yang mengguncang dunia Islam khususnya para pengkaji hadis telah mendapat perhatian di kalangan agamawan. Hadis yang telah disepakati kesahihannya tiba-tiba mendapat sanggahan dan kritikan baik sanad dan matan hadis, tidak ada lagi yang orisinil di mata Islamolog. Artikel ini menggunakan pendekatan sosio-historis guna membaca literatur sejarah dan pendekatan ilmu hadis sebagai bentuk kritik keakuratan argumentasi Islamolog. Teori yang dihasilkan Islamolog cenderung kepada pengkajian sejarah, sehingga transmisi periwayatan (sanad) dalam pandangan Islamolog tidak ilmiah hanya rekayasa orang-orang abad pertama dan kedua hijriyah. Hal ini tentu mengundang bantahan dan kritikan para ulama, terlepas adanya pergeseran keilmiahan suatu ilmu. Awal kemunculan Islam, standar ilmiah harus dengan hafalan yang tentu berbeda dengan zaman sekarang yang membutuhkan bukti tulisan.
\end{abstract}

\section{Kata Kunci:}

Islamolog, Kajian hadis

\begin{abstract}
:
This article discusses the study of hadith among Islamologists. The thought of Islamologists who shook the Islamic world, especially the scholars of hadith, has received attention among Islamic scholar. The hadith that has been agreed upon is valid and suddenly gets rebuttal and criticism from both the Sanad and the matn, there is no an authentic hadith in the eyes of Islamologists. This article uses a socio-historical approach to analyze historical literature and science of hadith approach as a form of criticism of the accuracy of Islamologist arguments. Theories produced by Islamologists tend to study history, so transmission (sanad) in the view of Islamologists is not scientific enough. Sanad fabricated by scholars in the first and second centuries of hijriyah. This certainly invites the rebuttal and criticism of the scholars, despite the shift in scientific knowledge. The beginning of the emergence of Islam, scientific standards must be memorized which is certainly different from today that requires written proof.
\end{abstract}

Keyword:

Islamologist, Hadith studies 


\section{Pendahuluan}

Umat Islam meyakini bahwa hadis Nabi saw. telah ada sejak awal kemunculan agama Islam, ${ }^{1}$ ketika pada masa Nabi saw. terjadi transmisi terhadap segala yang dikatakan, dilakukan, maupun yang disetujui Nabi saw. baik yang terkait dengan masyarakat umum maupun yang khusus berkenaan dengan hal-hal pribadi. Sebagai tauladan umat, Nabi menjadi sentral perhatian, dalam kedudukannya sebagai pemimpin, dan penyampai syariat Allah yang hampir semua perkataan dan perilakunya bermuatan hukum, ${ }^{2}$ kecuali sebagian yang terkait dengan urusan murni duniawi. Pembacaan sejarah menunjukkan rentang waktu yang cukup panjang terhadap hadis-hadis yang telah diriwayatkan baik oleh perorangan maupun banyak orang dari satu generasi ke generasi berikutnya sampai pada kolektor (mukharrij) hadis.

Rentang waktu yang panjang dalam kodifikasi hadis melahirkan asumsi Islamolog bahwa hadis muncul setelah perkembangan hukum Islam bukan bersamaan dengan kehadiran Nabi semenjak awal Islam. Sedang di lain sisi banyak hadis yang diriwayatkan oleh satu atau dua maupun lebih namun tidak memenuhi salah satu syarat-syarat hadis mutawatir selanjutnya disebut hadis ahad. ${ }^{3}$ Adapun hadis yang diriwayatkan oleh banyak periwayat pada tiap-tiap tingkatan sanad dinamakan dengan hadis mutawatir. ${ }^{4}$ Transmisi hadis baik yang ahad maupun mutawatir dalam pandangan ulama mendapat sanggahan Islamolog, menurutnya hadis di masamasa awal Islam tidak sefantastis jumlahnya sebagaimana abad kedua dan ketiga Hijriyah. Jumlah hadis yang membludak tidak linear dengan jumlah tulisan-tulisan hadis yang ditemukan di abad pertama. Fenomena ini bagi Islamolog melahirkan sikap apriori dalam mendalami kajian hadis.

Bangunan hadis dan ilmu hadis oleh para ulama hingga saat ini mendapat kritik dari kalangan Islamolog, seperti Ignaz Goldziher (1850-1921 M.), Joseph Schacht (1902-1969 M.), Harald Motzki, Michael Cook, G.H.A. Juynboll, dan masih banyak Islamolog lain, ${ }^{5}$ meskipun tidak semua Islamolog melakukan kritikan miring terhadap hadis Nabi saw. Islamolog memandang hadis sebagai kajian ilmu pengetahuan yang berawal dari sikap skeptis, sementara umat Islam memandang hadis sebagai sumber hukum kedua dalam Islam setelah al-Quran yang otoritasnya sebagai wahyu Ilahi.

\section{Sejarah Kajian Hadis di Kalangan Islamolog}

Term Islamologi merupakan istilah yang pertama kali diperkenalkan pada tahun 1970, sebagai dua bentuk pengkajian kritis terhadap dua studi keislaman, yaitu studi Islam (Islamologi) orientalis dan studi Islam para ulama klasik. Segala objek kajian orientalis terhadap Islam disebut Islamologi klasik (al-Islamiyyah al-Diniyyah). Sedang model studi turas $\backslash$ para ulama

\footnotetext{
${ }^{1}$ Fazlur Rahman, “The Living Sunnah and al-Sunnah wa al-Jama'ah”, dalam P. K. Hoya (ed.), Hadith and Sunnah: Ideals and Realities (Kuala Lumpur: Islamic Boook Trust, 2006 M.), h. 150.

${ }^{2}$ Muhammad 'Ajjaj al-Khatib, al-Sunnah qabl al-Tadwin (Bairut: Dar al-Fikr, 1997 M.), h. 15-16.

${ }^{3}$ Muhammad 'Ajjaj al-Khatib, Usul al-Hadis 'Ulumuh wa Mustalahuh (Bairut: Dar al-Fikr,1999 M.), h. 302.

${ }^{4}$ Mahmud al-Tahhan, Taysir Mustalah al-Hadis (Bairut: Dar al-Fikr, 2005 M.), h. 19.

${ }^{5}$ G.H.A. Juynboll, "Some Isnad Analytical Methods Illustrated on the Basis of Several Woman Demeaning Sayings from Hadith Literature", dalam W.A.I. Stokhof dan N.J.G. Kaptein (ed.), Beberapa Kajian Islam dan Indonesia, terj. Lilian D. Tedjasudhana (Jakarta: INIS, 1990 M.), h. 295-296.
} 
disebut ijtihad klasik (ijtihad taqlidi). Namun sering kali model studi Islamolog diterapkan oleh sarjana muslim, karena keduanya dinilai mirip dari objek kajian. ${ }^{6}$ Islamologi klasik yang dipelopori orientalis pada mulanya merupakan wacana orientalis tentang Islam. Wacana ini dahulu masih mengandung pengaruh-pengaruh pola pikir etnosentris. Ada dua sebab yang menjadikan studi ini bias etnis. Pertama, para orientalis membaca Islam secara subjektif, yaitu pembacaannya masih terkandung budaya peradaban mereka yang positivistik. Sehingga studi Islamologi bagi orientalis bertolak dari pra-anggapan dan aksioma filosofis, teologis dan ideologis tertentu. Kedua, para orientalis tidak memperhatikan kondisi sosial masyarakat Islam.

Sekian banyak bidang ilmu Islam yang menjadi kajian para Islamolog, salah satunya adalah hadis Nabi saw. mengenai Islamolog yang paling awal mengadakan kajian di bidang ini, belum ditemukan kepastian sejarah. Para ahli tarikh berbeda pendapat dalam hal ini. Menurut G.H.A. Joynboll, sebagaimana dikutip oleh Daniel W. Brown, sarjana Barat yang pertama kali melakukan kajian skeptik terhadap hadis adalah Alois Sprenger kemudian diikuti oleh Sir Willian Muir dalam karyanya Life of Mohamet dan mencapai puncaknya pada karya Ignaz Goldziher. ${ }^{7}$

Sedang menurut M. Mustafa Azami, Islamolog yang paling awal melakukan kajian hadis adalah Ignaz Goldziher, seorang Yahudi kelahiran Hongaria (1850-1920 M.) dalam karyanya yang berjudul: Muhamedanische Studien pada tahun 1980 yang berisi pandangannya tentang hadis. ${ }^{8}$ Pendapat ini dibantah oleh A.J. Wensinck bahwa Islamolog pertama yang mengkaji hadis adalah Snouck Hurgronje yang menerbitkan bukunya: Revre Coloniale Internationale tahun 1886. ${ }^{9}$ Sementara pendapat lain menyatakan bahwa Islamolog pertama yang mengkaji hadis adalah Alois Sprenger, dalam pendahuluan bukunya mengenai riwayat hidup dan ajaran nabi Muhammad saw. missionaris asal Jerman yang pernah lama tinggal di India ini, mengklaim bahwa hadis merupakan kumpulan anekdot (cerita-cerita bohong tapi menarik). ${ }^{10}$

Klaim ini diikuti oleh rekan satu misinya, yaitu William Muir, seorang Islamolog asal Inggris yang juga mendalami biografi nabi Muhammad saw. dan sejarah perkembangan Islam. Menurut Muir, dalam literatur hadis nama nabi Muhammad saw. sengaja dicatat untuk menutupi bermacam-macam kebohongan dan kesalahan sebagai bentuk rekayasa ("...the name of Mahomet was abused to support all possible lies and absurdities..."). ${ }^{11}$ Islamolog lain yang juga mengkaji hadis adalah Hamilton Alexander Roskeen Gibb, seorang Islamolog asal Inggris (1895-1971) melalui karyanya Mohammedanism dan Shorter Encyclopaedia of Islam, dilanjutkan oleh Joseph Schacht seorang Islamolog berkebangsaan Polandia (1902-1969) melalui karyanya The Origin

${ }^{6}$ Carool Kersten, The Applied Islamology Mohammed Arkoun, Makalah disampaikan pada Conference Religion on the Borders; New Challenges in the Academis Study of Religion pada 19-22 April di Stockholm Swedia.

${ }^{7}$ Daniel W. Brown, Rethinking Tradition in Modern Islamic Thought (Bandung: Mizan, 2000 M.), h. 111.

${ }^{8}$ Muhammad Mustafa Azami, Studies in Hadits Methodology and Literature (Indianapolis: American Trust Publications, 1977 M.), h. 94.

${ }^{9}$ Wahyudin Darmalaksana, Hadis di Mata Orientalis (Bandung: Benang Merah Press, 2004 M.), h. 88.

${ }^{10}$ Alois Sprenger, "On the Origin and Progress of Writing Down the Historical Facts among the Mosulmans," dalam Journal of Asiatic Society of Bengal 25 (1856-1857), h. 375-376.

${ }^{11}$ William Muir, The Life of Mahomet and the History of Islam to the Era of Hegira, Juz I (London: Oxford University Press, 1988 M.), h. xlii. 
of Muhammadan Jurisprudence, GHA. Joynboll dengan bukunya Muslim Tradition, Studies in Chronology, Provenance, and Authorship of Early Hadith, Bernard G. Weiss, dengan bukunya The Search for God's Law, serta masih banyak nama-nama lain seperti W. Montgomery Watt, Von Guerboum, Arberry, Jeffre, Ira Lapidus, dan John L. Esposito.

Perbedaan di atas tampaknya disebabkan dari sudut pandang periode dan pengaruh yang disebabkan Islamolog dalam kajian hadis. Bagi yang berpendapat bahwa Goldziher sebagai Islamolog pertama dalam kajian hadis melihatnya dari segi pengaruhnya terhadap Islamolog setelahnya, bukan dari periode awal kajian hadis Islamolog. Terlepas dari kontroversi di atas, hal yang perlu diketahui adalah bahwa ternyata Goldziher telah berhasil menanamkan keraguan terhadap autentisitas hadis, sehingga karyanya dianggap sebagai "kitab suci" oleh para Islamolog sendiri. $^{12}$ Di samping itu, kehadiran Joseph Schacht melalui bukunya The Origin of Muhammadan Jurisprudence, terbit pertama kali tahun 1950, yang kemudian dianggap sebagai "kitab suci kedua" oleh para Islamolog berikutnya, juga telah membawa dampak yang kuat terhadap sejumlah penelitian dan kajian hadis di kalangan Islamolog .

Kedua orang inilah yang mempunyai peranan besar dalam pengkajian hadis di kalangan Islamolog. Bahkan, menurut Ali Mustafa Ya'qub, untuk mengetahui kajian hadis di kalangan Islamolog cukup dengan hanya menelusuri pendapat kedua tokoh ini, karena para Islamolog sesudah mereka pada umumnya hanya mengikuti pendapat keduanya. Namun demikian, ada pula Islamolog yang memiliki pandangan yang lebih jernih dan bertentangan dengan kedua Islamolog di atas. Freeland Abbott, misalnya, dalam bukunya Islam and Pakistan (1908) membagi substansi hadis menjadi tiga kelompok besar:

1. Hadis yang menggambarkan kehidupan Nabi secara umum

2. Hadis yang dipermasalahkan karena hadis-hadis itu tidak konsisten dengan ucapan Nabi saw.

3. Hadis yang menceritakan wahyu yang diterima oleh Nabi. ${ }^{13}$

Meskipun klasifikasi oleh Freeland Abbott ini jauh berbeda dengan klasifikasi oleh kalangan ulama hadis, secara tidak langsung menunjukkan bahwa ia mengakui bahwa hadis benar-benar bersumber dari Nabi saw. Pengakuan yang lebih tegas diungkapkan oleh Nabia Abbott dalam bukunya Studies in Literary Papiry: Quran ic Commentary and Tradition (1957), menegaskan bahwa hadis-hadis Nabi saw. dapat ditelusuri keberadannya hingga masa Nabi saw. dan bukan buatan umat Islam setelah abad pertama Hijriyah.

Orisinalitas hadis dalam pandangan Islamolog terbagi menjadi dua kutub. Ada yang bersikap skeptis melihat hadis sebagai bentuk rekayasa orang-orang setelah Nabi saw. yang menyandarkan kepada periwayat yang dianggapnya kuat untuk memberikan jaminan orisinalitas hingga sampai kepada Nabi saw. dilain sisi ada yang mengatakan hadis benar-benar orisinalitasnya dapat ditelusuri hingga kepada Nabi saw. Namun pada umumnya pendapat yang pertama lebih banyak ditemukan di kalangan Islamolog dalam menyikapi Islam maupun hadis Nabi saw.

${ }^{12}$ Ali Mustafa Ya'qub, Kritik Hadis (Jakarta: Pustaka Firdaus, 2004 M.), h. 8.

${ }^{13}$ Maryam Jamilah, Islam dan Orientalisme, Sebuah Kajian Analitik (Jakarta: Raja Grafindo Persada, 1997M.), h. 175. 


\section{Sikap Islamolog terhadap Hadis Nabi saw.}

Sikap para Islamolog tidak lepas dari pencitraan mereka terhadap Nabi Muhammad. Sebab pembicaraan tentang hadis akan sinergi dengan nabi Muhammad yang perkataan, perbuatan, dan persetujuannya melahirkan hadis. Pada konteks ini, pencitraan nabi Muhammad di mata Islamolog dapat dipandang dari dua sisi. Satu sisi, nabi Muhammad dipandang sebagai Nabi dan Rasul yang telah membebaskan manusia dari kezaliman. Pandangan ini dikemukakan antara lain oleh De Boulavilliers dan Savary. Di sisi lain, nabi Muhammad dipandang sebagai paganis, penganut Kristen dan Yahudi yang murtad yang akan menghancurkan ajaran Kristen dan Yahudi, intelektual pintar yang memiliki imajinasi yang kuat dan pembohong, serta seorang tukang sihir yang berpenyakit ayan. Pandangan ini dikemukakan antara lain oleh D'Herbelot, Dante Alighieri, Washington Irving, Hamilton Gibb, Goldziher, dan Joseph Schacht. ${ }^{14}$

Sikap kedua di atas telah membentuk citra yang sama terhadap hadis, dalam pengertian bahwa mereka yang berpandangan negatif terhadap Nabi Muhammad Saw akan berpandangan negatif pula terhadap hadis. Demikian halnya, jika diklasifikasi secara keseluruhan ternyata kelompok Islamolog yang mencela hadis lebih banyak dibanding kelompok yang mengakui eksistensi hadis. Kenyataan ini menunjukkan bahwa mayoritas Islamolog memandang hadis secara negatif dan ini berakibat pada labilitas fondasi otentisitas dan kebenaran hadis di mata meraka, sehingga mereka tidak akan mengakui kebenaran hadis sebagai sesuatu yang berasal dari Nabi, termasuk sebagai sumber dan dasar (hujjah) ajaran Islam yang dapat dipercaya Orisinalitasnya.

Menurut Sa'ad al-Mursafi, sebagian Islamolog berpandangan skeptis terhadap keberadaan dan otentisitas hadis Nabi saw. ${ }^{15}$ Pandangan Islamolog bahwa pada masa-masa awal pertumbuhan Islam, hadis tidak tercatat sebagaimana al-Quran karena tradisi yang berkembang saat itu terutama pada masa Nabi dan sahabat adalah tradisi oral bukan tradisi tulisan dan sekaligus ada larangan secara umum untuk menulis sesuatu dari Nabi selain al-Quran meskipun ada juga hadis yang menyatakan sebaliknya secara khusus, maka dimungkinkan banyak hadis yang dipertanyakan otentitasnya atau sama sekali diragukan keberadaannya, terutama yang berkaitan dengan hukum yang diklaim oleh Islamolog sebagai hasil karya sahabat, tabi'in, atau para ulama dan fuqaha pada abad pertama Hijriyah dan permulaan abad kedua Hijriyah, dan menjadi suatu sistem yang matang sejak munculnya kompilasi hadis pada abad ketiga Hijriyah yang ingin menjadikan Islam sebagai agama yang multi dimensional, komprehensif yang mencakup seluruh aspek kehidupan. ${ }^{16}$

Historisitas hadis zaman Nabi saw. dan sahabat pada umumnya terjadi dalam transmisi oral dengan kekuatan hafalan para sahabat. Islamolog mencoba menawarkan kajian ilmiah dengan berupaya menghadirkan literatur yang tersisa di zaman Islam awal menyangkut orisinalitas kehujjahan hadis. Menurut analisis penulis, pergeseran paradigma keilmiahan yang

\footnotetext{
${ }^{14}$ Edward Said, Orientalisme (Bandung: Pustaka Salman, 1994 M.), h. 85. Lihat juga, Joesoef Sou'yb, Orientalisme dan Islam (Jakarta: Bulan Bintang, 1985 M.), h. 102-109. Lihat juga Tim Penyusun, Ensiklopedi Islam (Jakarta: Ichtiar Baru Van Hoove, 1994 M.), h. 56.

${ }^{15}$ Sa' ad al-Mursafi, al-Mustasriqun wa al-Sunnah (Kuwait: Maktabah al-Manar al-Islamiyah, 1994 M.), h. 19.

${ }^{16}$ Șubhi al-Șalih, 'Ulum al-Hadis wa Mustalahuh (Bairut: Dar al-‘Ilm li al- Malayin, 1988 M.), h. 19.
} 
tidak berhasil dibaca oleh Islamolog dengan menerapkan standar kebenaran sebuah ilmu di zaman modern berupa literatur tulisan, sementara objek kajian telah dalam terkubur zaman. Sehingga standar keilmiahan yang tepat mestinya mengacu pada kehidupan akademik Islam awal yang mengandalkan kekuatan hafalan para periwayat.

Argumentasi Goldziher yang menyatakan bahwa kebanyakan hadis yang terdapat dalam kitab-kitab koleksi hadis mengandung "semacam keraguan ketimbang dapat dipercaya". Ia menyimpulkan bahwa hadis-hadis itu bukan merupakan dokumen sejarah awal Islam, akan tetapi lebih merupakan refleksi dari tendensi-tendensi (kepentingan-kepentingan) yang timbul dalam masyarakat selama masa kematangan dalam perkembangan masyarakat itu. Ia mendasarkan pandangan pada beberapa hal, di antaranya adalah material yang ditemukan pada koleksi yang lebih akhir tidak merujuk kepada referensi yang lebih awal, penggunaan isnad juga mengindikasikan transmisi (periwayatan) hadis secara lisan, bukan merujuk kepada sumber tertulis. Selain itu, dalam hadis-hadis banyak ditemukan riwayat yang betentangan. Hal lain yang membuat skeptis terhadap otentisitas hadis adalah fakta adanya sahabat-sahabat junior yang meriwayatkan hadis lebih banyak daripada sahabat-sahabat senior yang diasumsikan mengetahui lebih banyak karena lamanya mereka berinteraksi dengan Nabi saw. ${ }^{17}$ Pandangan dari kebanyakan Islamolog, hadis hanya merupakan hasil karya ulama dan ahli fiqh yang ingin menjadikan Islam sebagai agama yang multi dimensional. Mereka menganggap bahwa hadis tidak lebih dari sekedar ungkapan manusia atau jiblakan dari ajaran Yahudi dan Kristen. Hamilton Gibb menyatakan bahwa hadis hanya merupakan jiblakan Muhammad dan pengikutnya dari ajaran Yahudi dan Kristen. Sementara Ignaz Goldziher dan Joseph Schatch, dua pemuka Islamolog, menyatakan bahwa hadis tidak bersumber dari nabi Muhammad, melainkan sesuatu yang lahir pada abad pertama dan kedua Hijriyah sebagai akibat dari perkembangan Islam. ${ }^{18}$

Literatur hadis pada akhir abad pertama dan kedua terlebih abad ketiga hijriyah yang dikaji Islamolog tidak dapat menjadi tolok ukur awal kemunculan hadis. Klaim Islamolog bahwa hadis lahir karena kepentingan mazhab fiqih sama sekali tidak berdasar, umat Islam dalam beragam mazhab tidak menvonis suatu hadis hanya diakui kualitasnya dikalangan mazhab tertentu. Selama suatu hadis memenuhi kriteria kasahihan sanad dan matan, maka umat Islam yang berbeda mazhab harus mengakui kedudukannya meskipun pada tataran interpretasi makna hadis dapat berbeda. Kodifikasi hadis yang hadir belakangan tidak layak menjadi indikator bahwa hadis baru muncul di masa tersebut, karena umat Islam awal sangat kuat berpegang pada sistem transmisi periwayatan (sanad). Dengan demikian Islamolog jika ingin melakukan kajian ilmiah terhadap hadis mestilah memperhatikan sanad sebagai standar keilmiahan sebelum era kodifikasi.

\footnotetext{
${ }^{17}$ Herbert Berg, The Development of Exegesis in Early Islam (Richmond: Curzon Press, 2000 M.), h. 9.

${ }^{18}$ Dikutip oleh Ahmad Muhammad Jamal, Muftarayat 'ala al-Islam (Bairut: Dar al-'Ilm li a-Malayin, 1987 M.), h. 98-99.
} 


\section{Pandangan Islamolog tentang Sanad}

Islamolog dalam mengkaji sanad tampaknya lebih banyak menyoroti tentang asal mula pemakaian sanad dalam periwayatan hadis. Pandangan Caetani, 'Urwah (w. 94 H.) sebagai orang pertama yang menghimpun hadis namun ia tidak menyertakan sanad. Sebelum itu pada masa 'Abd al-Malik (w. antara 70-80 H.), penggunaan sanad dalam periwayatan hadis juga belum dikenal. Caetani berpendapat bahwa penggunaan sanad baru dimulai pada masa antara 'Urwah dengan Ibn Ishaq (w. 151 H.). Berdasar pada pendangannya itu, ia berkesimpulan bahwa sebagian besar sanad yang terdapat dalam kitab-kitab hadis merupakan rekayasa para ahli hadis abad kedua, bahkan abad ketiga Hijriyah.

Pendapat lain dikemukakan oleh Horovits bahwa pemakaian sanad sudah dimulai sejak sepertiga akhir abad pertama Hijriyah. R. Jobson mengatakan bahwa pada pertengahan abad pertama Hijriyah mungkin sudah ada metode semacam sanad. Hipotesisnya didasarkan pada sejumlah sahabat yang sudah wafat sementara orang-orang yang tidak pernah bertemu dengan Nabi mulai meriwayatkan hadis-hadisnya, dengan sendirinya mereka akan ditanya oleh orangorang yang mendengarnya, dari siapa mereka mendapatkan hadis itu. Hanya saja metode sanad secara detail tentulah berkembang setelah itu secara bertahap. Henry Lammens, seorang missionaris asal Belgia, dan Leoni Caetani, missionaris Italia, menyatakan bahwa isnad muncul jauh setelah matan hadis ada dan merupakan fenomena internal dalam perkembangan Islam. ${ }^{19}$

Joseph Horovits berspekulasi bahwa sistem periwayatan hadis secara berantai (isnad) baru diperkenalkan dan diterapkan pada akhir abad pertama Hijriyah. Islamolog Jerman berdarah Yahudi ini menyatakan bahwa besar kemungkinan praktik isnad dipengaruhi oleh tradisi lisan sebagaimana dikenal dalam literatur Yahudi. ${ }^{20}$ Sementara itu, Joseph Schacht dalam The Origins of Muhammadan Jurisprudence, berpendapat bahwa bagian terbesar dari sanad hadis adalah palsu. Asumsi ini berdasarkan fakta historis bahwa orang-orang mengetahui bahwa sanad pada mulanya muncul dalam bentuk yang sangat sedikit dan sederhana, kemudian mencapai bentuk yang komplit pada paruh kedua abad ketiga Hijriyah. ${ }^{21}$ Dia menyatakan bahwa sanad merupakan hasil buatan para ulama abad kedua Hijriyah dalam menyandarkan sebuah hadis kepada tokoh-tokoh sebelumnya yang telah populer hingga akhirnya sampai kepada Nabi untuk mencari legitimasi yang kuat terhadap hadis tersebut.

Teori ini berawal dari pemahaman Schacht terhadap perkembangan hadis sejalan dengan perkembangan hukum Islam yang baru dikenal sejak pengangkatan para qadi pada masa Dinasti Umayyah. Sekitar akhir abad pertama Hijriyah, pengangkatan para qadi ditujukan kepada para fuqaha yang jumlahnya kian bertambah sehingga akhirnya menjadi aliran fiqh klasik (madzhab). Agar mendapat legitimasi yang kuat terhadap putusan hukum yang diambil, maka para qadi menyandarkannya kepada tokoh-tokoh sebelumnya yang dipandang mempunyai otoritas. Penyandaran tersebut tidak hanya sampai kepada generasi di atas mereka, tetapi sampai kepada

${ }^{19}$ Syamsuddin Arif, Orientalis dan Diabolisme Pemikiran (Jakarta: Gema Insani Press, 2008 M.), h. 30. Lihat Juga, Hanry Lammens, L'Islam: Croyances et Institutions, ed. III (Bairut: Imprimerie Chatolique, 1926 M.), h. 92-93. Lihat juga, Leone Chaetani, Annali Dell'Islam, Juz I (Milan: Ulrico Hoepli, t.th.), h. 28-31.

${ }^{20}$ Joseph Horovits, “Alter und Ursprung des Isnad” dalam Jurnal der Islam, Vol. 8 (1917-1918), h. 44.

${ }^{21}$ Joseph Schacht, The Origins of Muhammadan Jurisprudence (Oxford: University Press, 1975), 163. 
para sahabat dan akhirnya disandarkan kepada Nabi saw. Proses penyandaran ke belakang seperti inilah yang kemudian dikenal dengan istilah Projecting Back (proyeksi ke belakang). ${ }^{22}$

Berdasar pemahaman ini, Schacht berkesimpulan bahwa baik kelompok fiqh klasik maupun kelompok ahli hadis sama-sama melakukan rekayasa sanad hadis, oleh karenanya tidak ada hadis yang benar-benar bersumber dari Nabi tetapi merupakan produk yang lahir dari persaingan antara para ulama. Teori yang dihasilkan Schacht disanggah oleh Azami, menurutnya fiqh sudah berkembang sejak masa Nabi saw. karena fiqih merupakan hasil ijtihad, sementara sahabat telah melakukan ijtihad. Sehingga sulit untuk diterima tuduhan Schacht bahwa fiqh baru berkembang saat pengangkatan qadi pada masa Dinasti Umayah. Demi membuktikan data yang orisinil, Azami melakukan penelitian khusus tentang hadis-hadis Nabi yang terdapat dalam naskah-naskah klasik, naskah karya Suhail ibn Abi Salih (w. 138 H.). Abu Salih adalah murid Abu Hurairah, sahabat Nabi Saw. Sehingga sanad hadis dalam naskah itu berbentuk: Nabi Saw. Abu Hurairah - Suhail. Naskah ini berisi 49 hadis yang para periwayatnya diteliti oleh Azami sampai kepada generasi Suhail (generasi ketiga), termasuk tentang jumlah dan generasi mereka.

Penelitian yang dilakukan M.M. Azami menemukan bahwa pada generasi ketiga periwayat berjumlah sekitar 20-30 orang yang berdomisili secara terpencar seperti India, Turki, Maroko, dan Yaman, sementara teks hadis yang mereka riwayatkan redaksinya sama. Dengan demikian sangat mustahil menurut ukuran situasi dan kondisi saat itu mereka pernah berkumpul untuk membuat hadis sehingga menghasilkan redaksi yang sama. Sangat mustahil pula bila masing-masing mereka membuat hadis kemudian oleh generasi berikutnya diketahui bahwa redaksi hadis yang mereka buat sama. Penelitian yang dilakukan M. Azami sebagai salah satu usaha membuktikan orisinalitas hadis. Standar operasional kritik, baik pada sanad dan matan hadis yang ditawarkan oleh ulama jauh berbeda dengan standar yang dihasilkan Islamolog. Namun mesti dicermati teori kritik sanad yang ditawarkan Islamolog yang tentu seluruhnya juga tidak mengandung kekurangan.

\section{Kritik Sanad Perspektif Islamolog}

\section{Ignaz Goldziher}

Salah seorang tokoh besar Islamolog yang berasal dari Hungaria, lahir pada tahun 1850 M. Ia belajar di Budapest, Berlin dan Liepzig. Pada tahun 1873 ia pergi ke Syria dan belajar pada Syeikh Tahir al-Jazairi. Kemudian rihlah ke Palestina dan ke Mesir belajar dari sejumlah ulama al-Azhar. Sepulangnya dari al-Azhar ia diangkat menjadi guru besar di Universitas Budapset. Karya tulisnya sebagian besar membahas masalah-masalah keislaman, diplubisir dalam bahasa Jerman, Inggris dan Prancis, bahkan sebagian karyanya diterjemahkan ke dalam bahasa Arab. Dan yang paling berpengaruh dari karya-karya tulisannya adalah buku Muhammadanische Studien, dimana ia menjadi sumber rujukan utama dalam penelitian hadis di Barat. ${ }^{23}$

${ }^{22}$ Dalam pandangan Goldziher hadis merupakan akibat dari perkembangan Islam secara rel;igius, historis dan sosial selama dua abad pertama. Hadis-hadis tidak dapat dianggap sebagai dokumen sejarah pertumbuhan Islam, tetapi lebih sebagai refleksi dari berbagai mazhab yang muncul pada masyarakat Islam. Lihat, Ignaz Goldziher, Muslim Studies (London: George Allen and UNWIN, 1971 M.), h. 19.

${ }^{23}$ Leonard Binder, The Study of the Middle East (Canada: John Wiley \& Sons, 1976 M.), h. 66. 
Menurut Muhammad Mustafa Azami, Goldziher sebagai Islamolog pertama yang melakukan kajian mendalam tentang hadis. Kemudian disusul oleh Islamolog-Islamolog yang lainnya seperti J. Schacht, Juynboll dan lain-lain. Ignaz Goldziher berkesimpulan bahwa apa yang disebut hadis itu diragukan otentisitasnya sebagai sabda Nabi saw. dia menuduh bahwa penelitian hadis yang lakukan oleh ulama klasik tidak dapat dipertanggungjawabkan secara ilmiah karena kelemahan metodenya. Hal itu karena ulama lebih banyak mengunakan metode Kritik Sanad, dan kurang menggunakan Kritik Matan. Karenanya, Goldziher kemudian menawarkan metode kritik baru yaitu Kritik Matan saja. ${ }^{24}$

Para ulama klasik sudah menggunakan metode kritik matan, hanya saja apa yang dimaksud metode kritik matan oleh Goldziher itu berbeda dengan metode kritik matan yang dipakai oleh para ulama. Pandangan Goldziher, kritik matan itu mencakup berbagai aspek, seperti politik, sains, sosio-historis dan lain-lain. Kemudian mencotohkan sebuah hadis yang terdapat dalam kitab Sahih al-Bukhari, dimana menurutnya, al-Bukhari hanya melakukan kritik sanad dan tidak melakukan kritik matan. Sehingga setelah dilakukan kritik matan oleh Goldziher, hadis tersebut dinilai palsu.

a. Pendekatan sosio-historis

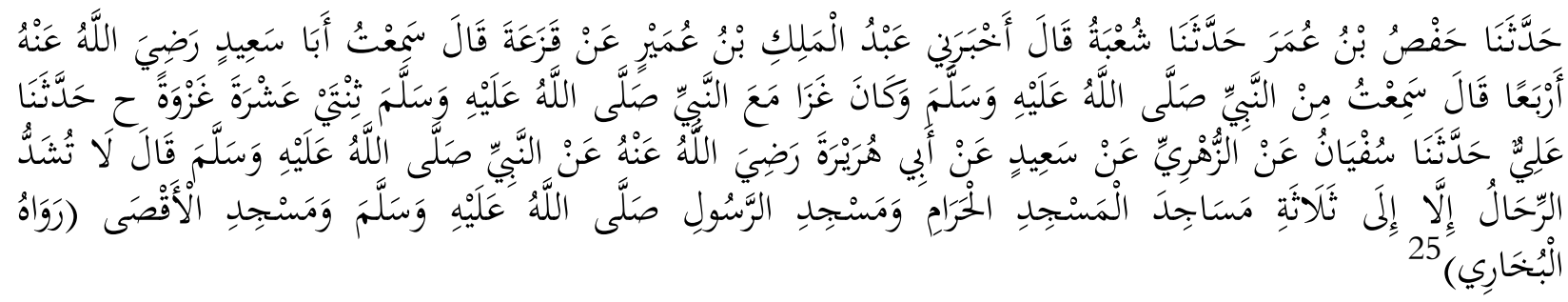

Artinya:

Telah menceritakan kepada kami Hafs ibn 'Umar telah menceritakan kepada kami Syu'bah berkata, telah mengabarkan kepada saya 'Abd al-Malik ibn 'Umair dari Qaza'ah berkata; Aku mendengar Abu Sa'id r.a. empat kali, berkata; Aku mendengar dari Nabi saw. Dia (Abu Sa'id r.a.) pernah ikut berperang bersama Nabi saw. sebanyak dua belas kali peperangan. Dan diriwayatkan, telah menceritakan kepada kami 'Ali telah menceritakan kepada kami Sufyan dari al-Zuhri dari Sa'id dari Abu Hurairah r.a. dari Nabi saw. bersabda: "Tidaklah ditekankan untuk berziarah kecuali untuk mengunjungi tiga masjid, Masjidil Haram, Masjid Rasul saw. dan Masjidil Aqsa”. (H.R. al-Bukhari).

Pendekatan sejarah yang dipakai Goldziher mengatakan bahwa Abd al-Malik ibn Marwan (Khalifah dari Dinasti Umayyah di Damaskus) merasa khawatir apabila 'Abdullah ibn al-Zubair (yang memproklamirkan dirinya sebagai Khalifah di Mekah) mengambil kesempatan dengan menyuruh orang-orang Syam (Syiria dan sekitarnya) yang sedang melakukan ibadah haji di Mekah untuk berbaiat kepadanya. Sehingga Abd al-Malik ibn Marwan berusaha agar orangorang Syam tidak lagi pergi ke Mekah, tetapi cukup hanya pergi ke Qubbah Shakhra di al-Quds yang pada saat itu menjadi wilayah Syam. M.), h. 127.

${ }^{24}$ M. M. Mustafa, Manhaj al-Naqad 'inda 'ala Muhadisin (Riyad: Syirkah al-Tiba'ah al 'Arabiyah, 1982

${ }^{25}$ Muhammad ibn Isma'il Abu 'Abdillah al-Bukhari al-Ju'fi, Șahih al-Bukhari, Juz II (Cet. I; Dar al-Tauq al-Najah, 1422 H), h. 60 . 
Demi mewujudkan usaha yang bersifat politis ini, 'Abd al-Malik ibn Marwan menugaskan Ibn Syihab al-Zuhri agar ia membuat hadis dengan sanad yang bersambung kepada Nabi saw. dimana isinya umat Islam tidak diperintahkan pergi kecuali menuju tiga masjid tersebut. ${ }^{26}$ Jadi kesimpulannya, hadis tersebut tidak sahih, karena ia buatan Ibn Syihab al-Zuhri, dan bukan sabda Nabi saw. meskipun hadis tersebut tercantum dalam kitab Sahih al-Bukhari yang diakui otentisitasnya oleh umat Islam, bahkan diakui sebagai kitab yang paling otentik sesudah al-Qu'an.

b. Kerancuan pendekatan sosio-historis

Pemikiran Goldziher telah disanggah oleh tiga ahli hadis kontemporer. Mustafa al-Siba'i (Guru besar Univesitas Damaskus) dalam bukunya al-Sunnah wa Makanatuha fi al-Tasyri' alIslam, Muhammad Ajjaj al-Khatib dalam bukunya al-Sunnah qabla al-Tadwin, dan M. M. Azami (Guru besar Ilmu Hadis Universitas King Su'ud Riyad) dalam bukunya Studies in Early Hadith Literature.

Menurut Azami, tidak ada bukti-bukti sejarah yang mempertahankan teori Goldziher, bahkan justru kebalikannya. Para ahli sejarah berbeda pendapat tentang kelahiran al-Zuhri, antara 50 sampai $58 \mathrm{H}$. Al-Zuhri juga belum pernah bertemu Abd al-Malik ibn Marwan sebelum tahun $81 \mathrm{H}$. Pada tahun $68 \mathrm{H}$ orang-orang Dinasti Umayyah berada di Mekah pada musim haji. Dari sini Azami berkesimpulan bahwa Abd al-Malik ibn Marwan baru berfikir membangun Qubbah Shakhra yang konon akan dijadikan pengganti Ka'bah itu pada tahun $68 \mathrm{H}$. Dengan demikian al-Zuhri pada saat itu baru berumur 10 sampai 18 tahun. Sehingga sangat tidak logis seorang anak baru berumur belasan tahun sudah populer sebagai sorang intelektual dan memiliki reputasi ilmiah di luar daerahnya sendiri, di mana ia mampu mengubah pelaksanaan ibadah haji dari Mekah ke Jerussalem. Lagi pula di Syam pada saat itu masih banyak terdapat para Sahabat dan para Tabi'in (generasi sesudah Sahabat), dimana mereka tidak mungkin diam saja melihat kejadian tersebut.

Argumen lain yang juga meruntuhkan teori Goldziher adalah teks hadis itu sendiri sebagaimana termaktub dalam kitab Sahih al-Bukhari. Di situ tidak ada isyarat pun yang menunjukkan bahwa ibadah haji dapat dilakukan di al-Quds, yang ada adalah isyarat pemberian keistimewaan kepada masjid al-Aqsa hal itu wajar karena mengingat masjid tersebut pernah dijadikan kiblat pertama umat Islam.

\section{Joseph Schacht}

Schacht lahir di Ratibor Polandia pada 15 Maret 1902. Ayahnya Eduard Schacht adalah seorang katolik roma dan guru sekolah luar biasa (SLB). Ibunya bernama Maria Mohr, pada tahun 1943 dia menikahi wanita Inggris yang bernama louise Isobel Dorothy, anak perempuan dari Joseph Coleman. Atmosfir religiusitas dan pendidikan dari keluarga telah memberinya kesempatan untuk menjadi akrab dengan tuntunan agama Kristen dan bahasa Hebrew. Inilah

${ }^{26}$ Bandingkan dengan, G.H.A. Juynboll, The Authenticity of the Tradition Literature Discussion in Modern Egypt (Leiden: E.J. Brill, 1969 M.), h. 113. 
yang menjadi titik poin penting yang nantinya akan membantu pemahamannya terhadap studi keagamaan. ${ }^{27}$

a. Teori kritik sanad Joseph Schacht

Sebelum membahas mengenai konsep-konsep maupun teori yang dikemukakan oleh Schacht, penulis akan mengutip metode yang digunakan dalam menelaah hadis yang kaitannya dengan hukum Islam, Bernard lewis mengatakan "Schacht's approach was neither theological nor juristic, but rather historical and sociological". ${ }^{28}$ Dari sini terdapat gambarkan bahwa pendekatan maupun metode yang ditempuh oleh Schacht bukanlah teologi maupun hukum, namun dia lebih condong untuk mengeksplorasi hukum Islam dari perspektif sejarah dan sosiologi.

Schacht dalam mengkaji hadis lebih banyak menyoroti aspek sanad (silsilah periwayatan) dari pada aspek matan (materi hadis). Sementara kitab-kitab yang dipakai dalam penelitiannya adalah kitab al-Muwatta' karya Imam Malik, kitab al-Muwatta karya Imam Muhammad alSyaibani, serta kitab al-Umm dan al-Risalah karya Imam al-Syafi'i. Menurut M.M Azami, kitabkitab ini lebih layak disebut kitab-kitab fiqh dari pada kitab-kitab hadis karena kedua jenis kitab ini memiliki karakteristik yang berbeda dengan kitab hadis. Dengan demikian, meneliti hadishadis yang terdapat dalam kitab-kitab fiqh hasilnya tidak akan tepat, penelitian hadis mestilah pada kitab-kitab hadis. ${ }^{29}$

Selanjutnya Schacht berpandangan bahwa secara umum sistem isnad mungkin valid untuk melacak hadis-hadis sampai pada ulama-ulama abad kedua, akan tetapi rantai periwayatan yang merentang ke belakang sampai kepada Nabi saw. dan para sahabat adalah palsu. Schacht berasumsi dari pendapat Ibn Sirin (w.110 H) yang mengatakan bahwa usaha untuk mempertanyakan dan meneliti sanad sudah dimulai sejak terjadinya fitnah (musibah perang saudara), dimana semua orang sudah tidak dapat dipercaya lagi, tanpa diteliti terlebih dahulu. Sementara diketahui bahwa fitnah yang bermula dari terbunuhnya al-Walid ibn Yazid (w $126 \mathrm{H}$ ) menjelang surutnya Daulah Umayyah adalah tahun yang lazim bagi akhir zaman keemasan lama yang saat itu Sunnah Nabi masih berlaku. Schacht menyimpulkan bahwa penisbatan pernyataan ini kepadanya adalah palsu. Bagaimana pun juga, tidak ada alasan untuk beranggapan bahwa praktek penggunaan isnad secara teratur lebih tua dari pada abad kedua hijriah.

Schacht menegaskan bahwa Hukum Islam belum eksis pada masa al-Sya'bi (w. $110 \mathrm{H}$ ). Penegasan ini memberikan pengertian bahwa apabila ditemukan hadis-hadis yang berkaitan dengan hukum Islam, maka hadis-hadis itu adalah buatan orang-orang yang hidup setelah alSya'bi. Ia berpendapat bahwa Hukum Islam baru dikenal semenjak masa pengangkatan para qadi (hakim agama). Pada khalifah dahulu (khulafa al-Rasyidin) tidak pernah mengangkat qadi. Pengangkatan qadi baru dilakukan pada masa Dinasti Bani Umayyah. ${ }^{30}$

\footnotetext{
${ }^{27}$ Akh Minhaji, Joseph Schacht's Contribution To The Study Of Islamic Law, Tesis, (Kanada: Institute of Islamic Studies McGill University, 1992 M.), h. 4-5.

${ }^{28}$ Bernard Lewis, Joseph Schacht, Bulletin of the School of Oriental and African Studies, Vol. 33, Part 2 (1970), h. 378-381.

${ }^{29}$ Muhammad Mustafa Azami, Dirasat fi al-Hadis al-Nabawi wa Tarikh Tadwinihi, (Bairut: Al-Maktab alIslami, 1980 M.), h. 398.

${ }^{30}$ Joseph Schacht, An Introduction To Islamic Law (Oxford: The Clarendon Press, 1964 M.), h. 34.
} 
Sekitar akhir abad pertama hijrah (715-720 M) pengangkatan qadi itu ditujukan kepada orang-orang "spesialis" yang berasal dari kalangan yang taat beragama. Sebab jumlah orangorang spesialis ini kian bertambah, maka akhirnya mereka berkembang menjadi kelompok aliran fiqh klasik. Hal ini terjadi pada dekade pertama abad kedua hijrah. Keputusan-keputusan hukum yang diberikan qadi ini memerlukan legitimasi dari orang-orang yang memiliki otoritas lebih tinggi. Oleh karena itu, mereka tidak menisbahkan keputusan-keputusan itu kepada diri mereka sendiri, melainkan menisbahkan kepada tokoh-tokoh sebelumnya. Misalnya saja orang-orang Iraq menisbahkan pendapat mereka kepada Ibrahim al-Nakha'i (w. $95 \mathrm{H}$ ) selanjutnya untuk memperoleh legitimasi yang lebih kuat, pendapat-pendapat itu dinisbahkan kepada tokoh yang memiliki otoritas paling tinggi, misalnya 'Abdullah ibn Mas'ud. Pada tahap terakhir, pendapatpendapat itu dinisbahkan kepada nabi Muhammad saw. Inilah rekontruksi terbentuknya sanad hadis menurut Schacht, yaitu dengan memproyeksikan pendapat-pendapat itu kepada tokohtokoh yang legitimit yang ada dibelakang mereka, inilah yang disebut oleh Schacht dengan teori projecting Back. $^{31}$

Menurut Schacht menuculnya aliran-aliran fiqh klasik ini membawa konsekuensi logis, yaitu munculnya kelompok oposisi yang terdiri dari ahli-ahli hadis. Pemikiran dasar kelompok ahli-ahli hadis ini adalah bahwa hadis-hadis yang berasal dari Nabi saw. harus dapat mengalahkan aturan-aturan yang dibuat oleh kelompok aliran-aliran fiqh. Demi tercapainya tujuan ini, kelompok ahli hadis membuat penjelasan-penjelasan dan hadis-hadis, seraya mengatakan bahwa hal itu pernah dikerjakan atau diucapkan oleh Nabi saw. Mereka juga mengatakan bahwa hal itu mereka terima secara lisan berdasarkan sanad yang bersambung dari para periwayat hadis yang dapat dipercaya. Kesimpulan dari teori Schacht ini adalah baik kelompok aliran-aliran fiqh klasik maupun kelompok ahli-ahli hadis, keduanya sama-sama pemalsu hadis. Sebagaimana dalam tesisnya dia mengatakan;

"We shall find that the bulk of legal traditions from the prophet known to malik originated in the generation preceding him, that is the second quarter of second century A.H., and we shall not meet any legal tradition from the prophet which can be considered authentic". ${ }^{32}$

Tesis schacht yang demikian menggemparkan pada dasarnya berbasis pada kerangka teori e silentio, yakni bahwa kesahihan sebuah hadis dapat dibuktikan dengan menilik keberadaan hadis pada suatu waktu tertentu, apakah hadis tersebut dipakai sebagai argumen legal dalam diskusi ataupun digunakan sebagai rujukan di dalam menentukan sebuah keputusan atau kebijakan hukum. ${ }^{33}$

b. Kerancuan teori Joseph Schacht

Sebelum kemunculan Islam, metode pemakaian periwayatan dengan "sanad" sudah dilakukan, namun tidak begitu jelas sejauh mana metode itu dipergunakan. Hal ini antara lain misalnya terdapat dalam kitab Yahudi Misyna. Selain itu, sistem isnad juga telah biasa dipakai

\footnotetext{
${ }^{31}$ Joseph Schacht, An Introduction To Islamic Law, h. 31-32

${ }^{32}$ Joseph Schacht, The Origins of Muhammadan Jurisprudence (London: Oxford University Press, 1967 M.) h. 149.

${ }^{33}$ M. Mustafa Al-Azami, On Schacht's Origins Of Muhammadan Jurisprudence (London: The Oxford Centre For Islamic Studies, 1996 M.), h. 116.
} 
dalam penukilan syair-syair Jahiliyah. Sedangkan dalam Islam sistem isnad muncul pertama kali pada masa hidup Nabi saw. dan telah berkembang menjadi ilmu yang mapan pada akhir abad pertama hijriah. Sistem ini dimulai dari praktek para sahabat dalam meriwayatkan hadis Nabi saw. ketika mereka saling bertemu. Hal ini terbukti dengan beberapa pengakuan sahabat Nabi sendiri, seperti: Umar ibn Khattab telah membagi tugas dengan tetangganya untuk mencari berita yang berasal dari Nabi. Kata Umar, bila tetangganya hari ini menemui Nabi saw. maka Umar pada esok harinya menemui Nabi. Siapa yang bertugas menemui Nabi dan memperoleh berita yang berasal atau berkenaan dengan Nabi, maka dia segera menyampaikan berita itu kepada yang tidak bertugas. ${ }^{34}$

Perkataan dari al-Bara ibn Azib al-Awsi "tidaklah kami semuanya (dapat langsung) mendengar hadis Rasulullah (karena diantara) kami ada yang tidak memilki waktu atau sangat sibuk. Akan tetapi ketika itu orang-orang tidak ada yang berani melakukan kedustaan terhadap hadis Nabi. Orang-orang yang hadir (menyaksikan terjadinya hadis Nabi) memberitakan (hadis itu) kepada orang yang tidak hadir". Hadis pada zaman Nabi telah diterima oleh para sahabat dengan cara dihafal dan dicatat. Dengan demikian, periwayatan hadis pada zaman Nabi telah berjalan dengan lancar.

Adapun teori "Projecting Back" Schacht, menurut Azami, tidaklah logis. Hal ini disebabkan adanya fakta bahwa terdapat sejumlah riwayat yang sama dalam bentuk dan makna dalam literatur para muhaddis in klasik dari sekte-sekte berbeda. Seandainya hadis hukum dipalsukan pada abad kedua dan ketiga hijriah, tidak akan ada hadis yang dimuat bersama dalam sumber sekte-sekte yang berbeda ini. Kemudian, Azami bertanya mengapa para ulama mau memilih dan mencantumkan orang-orang lemah untuk isnad mereka, sementara mereka sebenarnya juga bisa dengan mudah memilih figur-figur yang lebih terhormat. Menurut Azami hal ini tidaklah logis, yang lebih kuat lagi adalah argumen Azami bahwa dalam banyak kasus sebuah hadis diriwayatkan oleh sejumlah besar periwayat dari daerah yang berbeda-beda. Hampir mustahil mereka bertemu dan bersepakat melakukan pemalsuan ini. ${ }^{35}$

Namun demikian, argumentasi-argumentasi yang dikemukakan Azami untuk mematahkan teori Schacht dianggap masih kurang representatif. Hal itu disebabkan adanya kesenjangan argumentasi antara keduanya. Schacht tidak meyakini hukum Islam eksis pada abad pertama Hijriah, karena ia tidak menemukan data-data tertulis tentang hukum Islam yang dikodifikasikan pada masa itu. Sementara Azami dalam membuktikan keberadaan hukum Islam telah eksis pada abad pertama Hijriah adalah dengan menunjukkan sabda-sabda Nabi saw. kepada para sahabat terkait masalah hukum dengan data-data yang terdapat pada abad kedua atau ketiga Hijriah. Selain itu, Azami sebagaimana yang diyakini para Muhadis\in, menilai bahwa riwayat oral (lisan dengan metode hafalan) lebih kuat dibanding dengan riwayat tulisan.

\footnotetext{
${ }^{34}$ Abu Muhammad Mahmud ibn Ahmad ibn Musa ibn Ahmad ibn Husain, Umdah al-Qari’ Syarah Sahih al-Bukhari, Juz II (Bairut: Dar Ihya' al-Turas al-'Arabi, t. th), h. 104.

${ }^{35}$ Azami, Studies In Early Hadith Literature, terj. Ali Musthafa Yaqub (Jakarta: Pustaka Firdaus, 2000 M.), h. 237.
} 
Sementara Schacht karena ia tidak mempercayai tradisi kritik para informan hadis (Jarh wa Ta'dil), sehingga ia tidak mempercayai riwayat yang tidak tertulis. ${ }^{36}$

Fuad Seizgin memberikan komentar terhadap Schacht, bahwa dia kurang memahami fase perkembangan penulisan hadis. Menurut Sezgin, penulisan hadis (kitabah al-Hadis〉), bukan kodifikasi (Tadwin al-Hadis $\backslash$ ) sebagaimana yang dipahami oleh Schacht, telah dimulai pada abad pertama Hijriah, bahkan pada masa Rasulullah masih hidup, dalam bentuk catatan-catatan kecil. Kemudian pada seperempat akhir abad pertama Hijriah sampai seperempat awal abad kedua Hijriah, hadis dikodifikasikan (Tadwin al-Hadis $\backslash$ ) atas prakarsa Ibn Syihab al-Zuhri. Fase ketiga, Tasnif al-Hadis $\backslash$, yaitu membukukan hadis-hadis dengan metode merunutkan nama-nama sahabat, yang kemudian dinamakan dengan kitab al-Musnad.

Pada perkembangan selanjutnya, abad ketiga Hijriah, hadis dikodifikasikan dengan penulisan secara metodologis, yang kemudian dikenal dengan kitab-kitab Sahih. ${ }^{37}$ Tidak hanya itu saja, dia juga menunjukan adanya Sahifah-sahifah (lembaran-lembaran) hadis yang ditulis oleh para sahabat. Di antara para sahabat Nabi yang telah menulis sahifah-sahifah adalah: 'Abdullah ibn Amr ibn al-'Ash (65/784M), penulis sahifah hadis yang beliau namakan alSadiqah. Hadis-hadis yang terekam dalam sahifah ini beserta sanadnya bisa dilihat dalam kitab Musnad karya Ahmad ibn Hanbal. Samurah ibn Jundab (W.60 H/679 M), adalah penulis sahifah hadis. Sahifah tersebut beliau tujukan untuk anaknya, hal ini bisa dilihat dari statemen Ibn Sirin bahwa kitab Risalah Sahifah Samurah ibn Jundab yang diproyeksikan untuk anaknya memuat ilmu yang sangat luas. Ignaz Goldziher juga sempat mengkomparatifkan isi hadis yang terdapat dalam sahifah ini. Hadis-hadis dalam sahifah ini secara keseluruhan atau secara garis besar terdapat dalam Musnad Ahmad ibn Hanbal. Jabir ibn Abdullah (W.78 H/697M), ia adalah salah satu dari sejumlah sahabat yang memiliki naskah hadis dengan menuliskan hadis-hadis Nabi yang ia dapatkan baik melalui Nabi langsung ataupun dari sahabat Nabi.

3. G.H.A. Juynboll

Gautier H. A. Juynboll lahir pada tahun 1935 di Leiden, salah satu pusat kajian Islamolog terkemuka di Belanda. Ketertarikan Juynboll terhadap hadis telah ditunjukkan sejak jenjang akademik S1, ketika ia bergabung untuk mengedit separuh dari akhir kamus hadis, "Concordance et Indices de la Tradition Musulmanne" dari pertengahan huruf ghayn hinga akhir. ${ }^{38}$ Juynboll menyelesaikan pendidikan doktoralnya pada Fakultas Sastra Universitas Negeri Leiden Belanda pada tahun 1969 setelah merampungkan penelitian tentang pemikiran para teolog Mesir dalam rentang waktu 1890-1960 terhadap hadis. Penelitian Juynboll dilakukan selama dua tahun di Mesir dari tahun 1965 atas biaya Netherland Organization for The

\footnotetext{
${ }^{36}$ Muhammad Idris Mas'udi, Kritik Atas Proyek Kritik Hadis Joseph Schacht, h. 139.

${ }^{37}$ M. Abdurrahman, Studi Kitab Hadis (Yogyakarta: Teras, 2003 M), h. 157. Lihat juga, Mustafa Hasan, Ilmu Hadis (Cet. I; Bandung: Pustaka Pelajar, 2012 M), h. 154.

${ }^{38}$ Penggagas kamus ini adalah Islamisis Belanda, Arent Jan Wensinck (1882-1939) pada tahun 1916 sebanyak 8 volume dan diterbitkan pada tahun 1988. Kamus ini kemudian dialih bahasakan ke dalam bahasa Arab oleh Fu'ad 'Abd al-Baqi dengan judul al-Mu'jam al-Mufahras li Alfaz al-Hadis al-Nabawi. Ini merupakan kontribusi terbesar A.J. Wensink dalam kajian Islam disamping penulisan Encyclopedia of Islam. Baca Jacques Waardenburg, "Studi Islam di Belanda" dalam Azim Nanji (ed.), Peta Studi Islam: Orientalisme dan Arah Baru Kajian Islam di Barat, terj. Muammirotun (Yogyakarta: Fajar Pustaka Baru, 2003 M.), h. 106.
} 
Advancement of Pure Research (ZWO) dan diterbitkan oleh penerbit kajian Islam terkemuka di Belanda, E.J. Brill pada tahun 1969. ${ }^{39}$

a. Teori Common Link G.H.A Juynboll

Teori Common Link pada awalnya diintrodusir oleh Joseph Schacht yang kemudian dikembangkan secara massif oleh Juynboll. Common link merupakan istilah yang digunakan untuk menyebut periwayat tertua yang ditemukan dalam isnad yang menyebarkan hadis pada lebih dari satu murid. ${ }^{40}$ Teori ini berangkat dari asumsi dasar bahwa klaim kesejarahan sebuah hadis tidak hanya ditentukan oleh kualitas periwayat sebagaimana yang berkembang pada kritik hadis (konvensional) dalam tradisi muhaddis in, namun juga sangat ditentukan oleh kuantitas periwayat.

Teori common link sangat menarik dan kontroversial karena menggambarkan perspektif ideal Juynboll tentang jalur sanad yang diharapkannya memancar sejak awal dari Nabi melalui beberapa orang sahabat kepada tabi'in dan seterusnya hingga pada kolektor hadis (mukharrij). Dari hasil semedi intelektual Juynboll selama tiga puluh tahun terhadap sejarah dan perkembangan hadis, muncul sejumlah nomenklatur di sekitar teori common link sehingga berkembanglah berbagai istilah teknis (technical terms). Beberapa istilah teknis yang berkaitan dengan teori common link sebagai berikut.

1) Singgle strand (jalur tunggal), yaitu sebuah bundel isnad yang hanya memiliki jalur tunggal antara Nabi hingga periwayat yang berstatus common link, sehingga rantai periwayatan yang terjadi adalah: Nabi $\rightarrow$ sahabat $\rightarrow$ tabi'in $\rightarrow$ common link $\rightarrow$ sejumlah murid.

2) Fulan, ialah istilah yang digunakan untuk menyebut seorang periwayat yang menerima hadis dari seorang guru serta menyampaikan hadis tersebut hanya pada seseorang murid. Periwayat $\rightarrow$ fulan $\rightarrow$ periwayat.

3) Diving strand (jalur penyelam), yaitu bila ditemukan adanya sebuah jalur isnad yang tidak bertemu dengan periwayat berstatus common link, namun bertemu dengan isnad lainnya yang lebih dalam di tingkat tabi'in atau sahabat. Jalur periwayatan yang terbentuk adalah: Nabi $\rightarrow$ sahabat dan fulan $\rightarrow$ tabi'in dan fulan $\rightarrow$ fulan $\rightarrow$ fulan $\rightarrow$ kolektor.

4) Spider (jalur laba-laba), yaitu sebuah periwayatan yang terjadi dalam sebuah bundel isnad yang terdapat lebih dari sebuah jalur tunggal (dua/tiga/empat/lima atau lebih).

5) Partial common link (periwayat bersama sebagian), adalah periwayat yang menerima hadis dari seseorang (lebih) guru yang berposisi sebagai common link atau yang lain kemudian menyampaikannya kepada sejumlah murid. Partial common link dalam teori common link Juynboll memiliki posisi signifikan sebagai orang yang bertanggungjawab atas perubahan yang terjadi pada teks asli. Klaim kesejarahan partial common link ditentukan oleh kuantitas murid dalam periwayatan hadisnya, sehingga semakin banyak murid yang ia miliki, semakin kuatlah hubungan historis sebagai guru dan murid dalam periwayatan hadis.

${ }^{39}$ G.H.A Juynboll, Kontroversi Hadis di Mesir (1890-1960), terj. Ilyas Hasan (Bandung: Mizan, 1999 M.), h. v.

${ }^{40}$ Juynboll, "Some Isnad Analytical Methods Illustrated on the Basis of Several Woman-Demeaning Saying from Hadith Literature," dalam W.A.L. Stokoff dan N.J.G. Kaptein (eds.), Beberapa Kajian Islam dan Indonesia, terj. Lilian D. Tedjasudhana (Jakarta: INIS, 1990), 295-296. 
6) Seeming common link (yang tampak sebagai periwayat bersama), yaitu adanya figur yang menyerupai common link dalam sebuah bundel isnad yang terdiri dari berbagai jalur tunggal.

7) Inverted common link (periwayat bersama terbalik), yaitu jika ditemukan berbagai jalur tunggal yang berasal dari saksi mata yang berbeda kemudian masing-masing saksi mata menyampaikan pada seorang murid hingga bertemu dengan inverted common link.

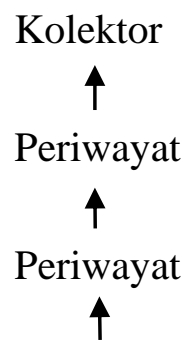

Interved common link

$\begin{array}{ccc}\stackrel{\uparrow}{\longrightarrow} & \text { Periwayat } & \text { Periwayat } \\ \text { Periwayat } & \uparrow & \uparrow \\ \uparrow & \text { Periwayat } & \text { Periwayat } \\ \text { Saksi mata } & \uparrow & \uparrow\end{array}$

Kemunculan teori common link menjadi kontroversi dikarenakan memiliki implikasi negatif terhadap kesejarahan hadis. Berdasarkan teori ini, common link dipandang sebagai sumber kemunculan hadis dan dianggap bertanggungjawab atas asal-usul hadis. Sementara dalam periwayatan hadis, Juynboll menemukan fenomena bahwa penyebaran periwayatan dalam berbagai koleksi kitab hadis, bahkan kitab hadis standar, ternyata baru terjadi pada periwayat ke3/4/5 setelah Nabi atau pada tingkatan tâbi ‘în kecil, sehingga Juynboll menganggap isnâd yang asli adalah isnâd setelah terjadinya penyebaran itu yang ditandai dengan adanya periwayat yang berstatus common link. Jika sanad setelah common link dapat dipertanggungjawabkan kesejarahannya, maka sanad yang menuju pada Nabi adalah palsu, sehingga dengan demikian matn hadis dapat dipastikan berasal dari periwayat common link ini. Asumsi Juynboll berlandaskan kritik sejarah yang mempersyaratkan kuantitas periwayat untuk mendukung klaim kesejarahan hadis. Jika hadis hanya diriwayatkan oleh satu orang sahabat dari Nabi, kemudian juga hanya diterima oleh seorang tâbi'î, Juynboll merasa kesulitan untuk mengandalkan reliabilitas periwayat tunggal ini, karena tidak mendapatkan cukup bukti tentang kesejarahan periwayat.

Selain persoalan kesejarahan, asumsi Juynboll ini juga berdasarkan pada teori asal-usul isnâd dalam Islam yang baru dimulai pada akhir abad I Hijriyah, ketika menurutnya hampir seluruh sahabat telah meninggal beberapa dekade sebelum isnâd menjadi alat untuk mendeteksi hadis. Dengan demikian, secara historis hadis tidak muncul pada masa Nabi atau sahabat dan baru muncul pada masa tâbi 'în bahkan atbâ' tâbi‘în, karena periwayat dengan status common link didominasi oleh periwayat pada generasi ini.

b. Kritik terhadap teori Common link 
Menelusuri pemikiran hadis yang diintrodusir oleh Juynboll, hampir dalam banyak detail pemikirannya merupakan pengembangan dari teori Schacht tentang hadis. Pengembangan yang inovatif nampak dalam elaborasi Juynboll tentang teori common link. Teori common link yang awalnya dipopulerkan oleh Schacht di tangan Juynboll menjadi sebuah teori yang mapan dan ekstensif. Tidak bergeser dari kesimpulan Schacht yang memandang adanya common link dalam sebuah periwayatan dapat dipandang sebagai indikasi pemalsuan hadis, Juynboll memperkenalkan banyak istilah teknis baru yang sama sekali tidak disebut Schacht ketika membincang common link.

Teori common link yang menjadi bagian dari upaya memberikan penanggalan terhadap hadis untuk menguji historisitas dan otentitas hadis dari Nabi saw. ${ }^{41}$ dapat digunakan untuk melakukan kajian yang menyegarkan terhadap hadis. Dengan melakukan revisi terhadap asumsi yang mendasari teori common link sebagai analisis untuk mengidentifikasi pemalsu hadis, kesarjanaan muslim dapat memanfaatkan teori ini untuk menelisik sejarah periwayatan hadis tertentu secara terbuka. Fenomena common link atau yang disebut oleh al-Turmuzli sebagai madar dalam hadis memberikan petunjuk tentang tokoh, tempat dan masa sebuah periwayatan hadis mulai menyebar dan diketahui oleh publik. ${ }^{42}$

Demikian pula tawaran analisis isnad sebagai revisi atas metode penelitian hadis yang berlaku di kalangan muhaddis in, dalam batas-batas tertentu dapat dimanfaatkan dalam pengkajian sejarah periwayatan hadis yang hingga saat ini masih menawarkan eksotisme kajian. Selain itu, karena analisis isnad ini mendasarkan diri pada asumsi common link dalam mazhab Schactian, maka revisi atas pandangan ini juga merupakan sebuah kemestian.

Tawaran analisis isnad yang dilakukan oleh Juynboll ini sebenarnya juga masih membutuhkan kajian penyempurna sebagaimana yang dikembangkan oleh Harald Motzki melalui pendekatan isnad cum matn analysis. Jika dalam analisis isnad Juynboll yang terlihat hanya menekankan pada tingkat studi sanad, maka pendekatan ini diperbaiki Motzki untuk melibatkan matan atau teks hadis. Menurut Motzki, kualitas periwayat ditentukan oleh matan atau teks yang diriwayatkan oleh periwayat sebagai sumber primer sementara sumber-sumber dalam kitab rijal dan jarh wa al-ta'dil tentang periwayat didudukkan sebagai informasi sekunder. $^{43}$

\footnotetext{
${ }^{41}$ Terdapat perbedaan metodologis yang digunakan oleh para pengkaji hadis dari kalangan Islam dan Barat. Pengkaji Barat melakukan hadith's dating (penanggalan hadis) sebagai landasan untuk memastikan historisitas dan melakukan rekonstruksi sejarah terhadap peristiwa yang dikatakan banyak orang terjadi pada masa awal Islam, sementara pendekatan takhrîj dan naqd al-hadîth digunakan dalam tradisi kesarjanaan Muslim. Baca Komaruddin Amin, "Problematika Ulumul Hadith", 3.

${ }^{42}$ Elaborasi tentang pemanfaatan teori common link dapat dibaca dalam Nur Mahmudah, "Hadits Dating (Memanfaatkan Teori Common link Juynboll)" dalam Hermeneutik, Vol. 2, No. 2, 2007, h. 2-23.

${ }^{43}$ Cara kerja pendekatan isnad cum matan adalah melakukan penelusuran terhadap seluruh periwayatan hadis dalam berbagai kitab baik kanonik (kutub al-sittah), Pra-canonic (Musnad al-Tayalisi, Ibn Rahawayh, Musannaf 'Abd al-Razzaq) maupun post-canonic (Sunan al-Bayhaqi, Sunan Ibn Hibban, Sahih Ibn Khuzaymah). Pendekatan ini sebenarnya hampir senada dengan upaya muqaranat al-mutun (perbandingan berbagai matn dalam hadis tertentu) yang biasa dikenal dalam tradisi kesarjanan muslim yang mencakup inversigasi atas redaksional matn seperti ziyadah, idraj, tahrîf, tashif, maupun aspek makna (kandungan) matn. Hanya saja dalam tradisi sarjana muslim, penelitian matan ini tidak menjadi bagian dari upaya naqd al-sanad sebagaimana yang diinginkan oleh Motzki. Ali Mansur, Teori Common Link G.H.A Juynboll: Melacak Akar Kesejarahan Hadith Nabi (Yogyakarta: LKiS, 2007 M.), h. 90 - 91
} 
Pandangan Juynboll yang hampir merupakan perpanjangan tangan dari teori yang dibangun oleh Schacht telah banyak mendapatkan apresiasi dari sarjana Muslim. Mustafa Azami menulis satu buku khusus untuk mendiskuskusikan teori Schacht dan menunjukkan kelemahan teori ini. Beberapa pemikiran yang diadopsi Juynboll dari Schacht adalah persoalan isnad keluarga. Azami menyanggah penolakan Schacht atas keseluruhan keluarga dalam periwayatan hadis dan menunjukkan historisitas beberapa isnad keluarga. Bagi Azami persoalan yang menimpa beberapa isnad keluarga yang bermasalah tidak dapat digeneralisir dan diberlakukan bagi keseluruhan fenomena ini sehingga kesimpulan Schacht yang diamini oleh Juynboll tidak dapat dipertahankan.

Diya' al-Rahman al-Azami juga menulis sanggahan terhadap teori common link dengan melakukan kajian terhadap fenomena single strand (jalur tunggal) yang ternyata banyak diketemukan syawahid dan tawabi' sehingga jalur-jalur ini sebenarnya bukan sebuah jalur tunggal sebagaimana yang diasumsikan oleh Juynboll dan diragukan kesejarahannya. Wallahu 'alam.

\section{Kesimpulan}

Kajian hadis dikalangan Islamolog telah lama muncul, sehingga terjadi perbedaan pendapat tentang siapa yang paling awal melakukan kajian hadis. Perbedaan tersebut disebabkan perspektif apa yang digunakan, ada yang menjadikan periode sebagai tolak ukur, tetapi ada pula yang melihatnya berdasarkan tokoh yang paling besar pengaruhnya. Namun yang dapat disepakati secara umum bahwa Goldziher sebagai Islamolog pertama yang telah berhasil menanamkan keraguan terhadap otentisitas hadis dan karyanya dianggap sebagai "kitab suci" dikalangan Islamolog.

Orisinalitas hadis menurut Islamolog dapat dilihat dalam beberapa teori yang ditawarkannya. Goldziher mengkritik ulama hadis karena kebanyakan hanya melakukan kritik sanad saja, sehingga Islamolog ini hanya menawarkan kritik matan dengan menggunakan pendekatan sejarah, sains, politik dan ilmu umum lainnya. Islamolog selanjutnya, Joseph Schacth dengan teori projektion back mengkritik sanad hadis dari segi penyandarannya yang diklaim bahwa sanad pada fase belakangan melakukan pembengkakan dengan menyandarkan kepada ulama-ulama besar masa sebelumnya. G.H.A. Juynboll dengan teori common link melakukan kritik terhadap periwayat yang menjadi jalur tersebarnya sebuah hadis. Berdasarkan teori di atas, menurut Islamolog hadis yang telah disepakati kesahihannya oleh ulama hadis tidak dapat dipertanggungjawabkan orisinalitas dan otentisitasnya.

Melalui kajian hadis dikalangan Islamolog dapat menjadi khazanah pengetahuan baru bahwa hadis Nabi saw. bukan hanya dipelajari oleh umat Islam. Bagi masyarakat luas, khususnya umat Islam tulisan ini sebagai informasi dan motivasi untuk mendalami pengetahuan hadis sebagai pondasi agama Islam yang mesti dilestarikan dari guncangan orang-orang yang ingin meruntuhkan orisinalitasnya. 


\section{DAFTAR PUSTAKA}

Al-Ju'fi, Muhammad ibn Isma'il Abu 'Abdillah al-Bukhari. Sahih al-Bukhari. Cet. I. Dar al-Tauq alNajah, $1422 \mathrm{H}$.

Al-Mursafi, Sa'ad. al-Mustasriqun wa al-Sunnah. Kuwait: Maktabah al-Manar al-Islamiyah, 1994 M. Al-Salih, Subhi. 'Ulum al-Hadis $\backslash$ wa Mustalahuh. Bairut: Dar al-'Ilm li al- Malayin, 1988 M.

Al-Tahhan, Mahmud. Taisir Mustalah al-Hadis $\backslash$. Bairut: Dar al-Fikr, 2005 M.

Abdurrahman, M. Studi Kitab Hadis. Yogyakarta: Teras, 2003 M.

Arif, Syamsuddin. Orientalis dan Diabolisme Pemikiran. Jakarta: Gema Insani Press, 2008 M.

Azami, Muhammad. Mustafa. Studies In Early Hadith Literature. Terj. Ali Mustafa Yaqub Jakarta: pustaka firdaus, $2000 \mathrm{M}$.

. Dirasat fi al-Hadis $\backslash$ al-Nabawi wa Tarikh Tadwinihi. Bairut: Al-Maktab al-Islami, 1980 M.

- Studies in Hadits Methodology and Literature. Indianapolis: American Trust Publications, 1977 M.

. Manhaj al-Naqad 'inda 'ala Muhadis\in. Riyad: Syirkah al-Tiba'ah al 'Arabiyah, 1982 M.

Berg, Herbert. The Development of Exegesis in Early Islam. Richmond: Curzon Press, 2000 M.

Brown, Daniel W. Rethinking Tradition in Modern Islamic Thought. Bandung: Mizan, 2000 M.

Chaetani, Leone. Annali Dell'Islam. Milan: Ulrico Hoepli, t.th.

Darmalaksana, Wahyudin. Hadis di Mata Orientalis. Bandung: Benang Merah Press, 2004 M.

Hanry Lammens, L'Islam: Croyances et Institutions. Bairut: Imprimerie Chatolique, 1926 M.

Hasan, Mustafa. Ilmu Hadis. Cet. I. Bandung: Pustaka Pelajar, 2012 M.

Horovits,Joseph. “Alter und Ursprung des Isnad”. Jurnal der Islam. Vol. 8 (1917-1918).

Ibn al-Salah, Abu 'Amr 'Usıman ibn 'Abd al-Rahman. 'Ulum al-Hadis'. al-Madinah al-Munawwarah: al-Maktabah al-Islamiyyah, $2002 \mathrm{M}$.

Jamal, Ahmad Muhammad. Muftarayat 'ala al-Islam. Bairut: Dar al-'Ilm li a-Malayin, 1987 M.

Jamilah, Maryam. Islam dan Orientalisme, Sebuah Kajian Analitik. Jakarta: Raja Grafindo Persada, 1997M.

Juynboll, G.H.A. The Authenticity of the Tradition Literature Discussion in Modern Egypt. Leiden: E.J. Brill, 1969 M.

. Kontroversi Hadis di Mesir. Terj. Ilyas Hasan. Bandung: Mizan, 1999 M.

Lewis, Bernard. Joseph Schacht. Bulletin of the School of Oriental and African Studies. Vol. 33. Part 2 (1970).

Mansur, Ali. Teori Common Link G.H.A Juynboll: Melacak Akar Kesejarahan Hadis Nabi. Yogyakarta: LKiS, 2007 M.

Minhaji, Akh. Joseph Schacht's Contribution To The Study Of Islamic Law. Tesis. Kanada: Institute of Islamic Studies McGill University, $1992 \mathrm{M}$.

Muir, William. The Life of Mahomet and the History of Islam to the Era of Hegira. London: Oxford University Press, $1988 \mathrm{M}$.

Nanji, Azim. Peta Studi Islam: Orientalisme dan Arah Baru Kajian Islam di Barat. Terj. Muammirotun. Yogyakarta: Fajar Pustaka Baru, 2003 M.

Rahman, Fazlur. "The Living Sunnah and al-Sunnah wa al-Jama'ah”. dalam P. K. Hoya. Hadith and Sunnah: Ideals and Realities. Kuala Lumpur: Islamic Boook Trust, 2006 M. 
Said, Edward. Orientalisme. Bandung: Pustaka Salman, 1994 M.

Schacht, Joseph. An Introduction To Islamic Law. Oxford: The Clarendon Press, 1964 M. The Origins of Muhammadan Jurisprudence. London: Oxford University Press, 1967 M.

Sou'yb, Joesoef. Orientalisme dan Islam. Jakarta: Bulan Bintang, 1985 M.

Sprenger, Alois. On the Origin and Progress of Writing Down the Historical Facts among the Mosulmans. Journal of Asiatic Society of Bengal 25 (1856-1857).

Tim Penyusun Ensiklopedi Islam. Jakarta: Ichtiar Baru Van Hoove, 1994 M.

Ya’qub, Ali Mustafa. Kritik Hadis. Jakarta: Pustaka Firdaus, 2004 M. 